\title{
AUXOTYPING OF NEISSERIA GONORRHOEAE ISOLATED IN THE UNITED KINGDOM
}

\author{
C. G. Copley and S. I. Egglestone
}

Public Health Laboratory, Myrtle Road, Kingsdown, Bristol BS2 8EL

SUMmary. One hundred and twenty consecutive isolates of Neisseria gonorrhoeae from the County of Avon, UK, were examined by auxotyping and penicillin susceptibility testing. Requirements for proline (Pro), arginine (Arg), hypoxanthine (Hyp), uracil (Ura) and methionine (Met) were determined with a modified Heckels' medium. Prototrophic strains accounted for $29.9 \%$ of isolates and were a heterogeneous group as judged by penicillin susceptibility testing. The group most generally susceptible to penicillin required Arg-Hyp-Ura, and represented $27.5 \%$ of isolates. The Pro-Arg ${ }^{\circ}-\mathrm{Ura}$ auxogroup $(10 \%$ of isolates) had the narrowest range of penicillin susceptibility. Prototrophic strains had a reduced growth rate on arginine-free medium. Investigations of this phenomenon and suitable methods for auxotyping are reported.

\section{INTRODUCTION}

Since Catlin (1973) developed a defined medium capable of supporting the growth of most gonococcal isolates, auxotyping has become the most accepted method for differentiating between strains of Neisseria gonorrhoeae. Most methods are based on requirements in such a medium for proline (Pro), arginine (Arg), hypoxanthine (Hyp) and uracil (Ura). Although auxotyping has been performed at several centres in America, Canada, Sweden, Holland and France (Carifo and Catlin, 1973; Moberg, 1975; Knapp et al., 1978; Hendry and Stewart, 1979; Le Faou, Guy and Riou, 1979; Noble, 1980; Ansink-Schipper et al., 1982) for a number of years, little has been published on the auxotyping of isolates in Britain (Copley and Egglestone, 1982; Jephcott, Egglestone and Copley, 1982). The geographical variation of auxotypes has been exemplified by Hendry and Stewart (1979) who noted that a previously unreported auxotype accounted for over $30 \%$ of Canadian isolates.

In this paper we report the results of auxotyping 120 consecutive isolates from the County of Avon, U.K. In addition to the usual tests we also tested for methionine dependence and the ability of ornithine to replace an arginine requirement. Furthermore, the complexity of Catlin's medium has led several groups of workers (Carifo and Catlin, 1973; La Scolea and Young, 1974; Dr J. E. Heckels, personal communication) including ourselves, to develop simplified formulations; our observations on such modifications are included. 
TABLE I

Composition of auxotyping media

\begin{tabular}{|c|c|c|c|c|c|c|}
\hline \multirow[b]{2}{*}{ Media constituents } & \multicolumn{6}{|c|}{ Concentration $(\mu \mathrm{g} / \mathrm{ml})$ of constituent in each medium } \\
\hline & Hunter* & Catlin & La Scolea & Heckels & Hendry & CGC \\
\hline $\begin{array}{l}\text { Aminoacids } \\
\text { L-alanine } \\
\text { L-arginine. } \mathrm{HCl} \\
\text { L-asparagine. } \mathrm{H}_{2} \mathrm{O} \\
\text { L-aspartic acid } \\
\text { L-citrulline } \\
\text { L-cysteine. } \mathrm{HCl} . \mathrm{H}_{2} \mathrm{O} \\
\text { L-cystine } \\
\text { L-glutamic acid } \\
\text { L-glutamine } \\
\text { Glycine } \\
\text { L-histidine } \\
\text { L-isoleucine } \\
\text { L-leucine } \\
\text { L-Lysine. HCl } \\
\text { L-methionine } \\
\text { L-phenylalanine } \\
\text { L-proline } \\
\text { L-serine } \\
\text { L-threonine } \\
\text { L-tryptophan } \\
\text { L-tyrosine } \\
\text { L-valine } \\
\text { Spermine. } 4 \mathrm{HCl}\end{array}$ & $\begin{array}{r}0 \\
50 \\
0 \\
2000 \\
0 \\
0 \\
500 \\
0 \\
100 \\
0 \\
0 \\
200 \\
400 \\
0 \\
0 \\
0 \\
200 \\
50 \\
200 \\
0 \\
0 \\
400 \\
0\end{array}$ & $\begin{array}{r}100 \\
150 \\
25 \\
500 \\
0 \\
61 \\
36 \\
1300 \\
50 \\
25 \\
18 \\
30 \\
90 \\
50 \\
15 \\
25 \\
50 \\
50 \\
50 \\
80 \\
54 \\
60 \\
87\end{array}$ & $\begin{array}{r}0 \\
250 \\
0 \\
125 \\
0 \\
1200 \\
50 \\
188 \\
0 \\
0 \\
0 \\
125 \\
0 \\
0 \\
190 \\
0 \\
250 \\
125 \\
0 \\
0 \\
0 \\
0 \\
0 \\
0\end{array}$ & $\begin{array}{r}0 \\
40 \\
0 \\
0 \\
0 \\
260 \\
0 \\
0 \\
100 \\
0 \\
20 \\
30 \\
50 \\
50 \\
15 \\
0 \\
20 \\
50 \\
0 \\
0 \\
0 \\
60 \\
0\end{array}$ & $\begin{array}{c}44 \cdot 5 \\
0 \\
0 \\
0 \\
92 \\
29 \cdot 5 \\
15 \\
0 \\
73 \\
0 \\
39 \\
33 \\
33 \\
36 \cdot 5 \\
37 \cdot 5 \\
0 \\
230 \\
12 \cdot 5 \\
60 \\
51 \\
0 \\
29 \cdot 5 \\
50\end{array}$ & $\begin{array}{r}50 \\
100 \\
0 \\
0 \\
0 \\
260 \\
0 \\
1000 \\
50 \\
0 \\
20 \\
30 \\
50 \\
50 \\
20 \\
0 \\
50 \\
50 \\
50 \\
50 \\
50 \\
60 \\
0\end{array}$ \\
\hline $\begin{array}{l}\text { Bases } \\
\text { Cytosine } \\
\text { Guanine. } \mathrm{HCl} \\
\text { Hypoxanthine } \\
\text { Uracil }\end{array}$ & $\begin{array}{r}20 \\
20 \\
0 \\
0\end{array}$ & $\begin{array}{l}0 \\
0 \\
3 \cdot 2 \\
8\end{array}$ & $\begin{array}{l}0 \\
0 \\
2 \cdot 5 \\
5\end{array}$ & $\begin{array}{r}0 \\
0 \\
10 \\
40\end{array}$ & $\begin{array}{l}0 \\
0 \\
47 \cdot 5 \\
56\end{array}$ & $\begin{array}{r}0 \\
0 \\
5 \\
10\end{array}$ \\
\hline $\begin{array}{l}\text { Carbohydrates etc } \\
\text { Glucose } \\
\text { Glycerol } \\
\text { Oxaloacetate. } \mathrm{Na} \\
\text { Pyruvate. } \mathrm{Na} \\
\text { Acetate. } \mathrm{Na} \\
\text { Citrate. } \mathrm{Na} \\
\text { Lactate. } \mathrm{Na}\end{array}$ & $\begin{array}{r}2500 \\
0 \\
0 \\
0 \\
0 \\
0 \\
0\end{array}$ & $\begin{array}{r}5000 \\
920 \\
200 \\
0 \\
3400 \\
0 \\
250\end{array}$ & $\begin{array}{c}7500 \\
0 \cdot 125 \%(v / v) \\
250 \\
0 \cdot 125 \%(v / v) \\
1500 \\
1125 \\
0\end{array}$ & $\begin{array}{r}1000 \\
1000 \\
20 \\
0 \\
250 \\
0 \\
2500\end{array}$ & $\begin{array}{r}5000 \\
920 \\
0 \\
0 \\
3400 \\
0 \\
558\end{array}$ & $\begin{array}{r}2500 \\
1000 \\
100 \\
0 \\
1000 \\
0 \\
250\end{array}$ \\
\hline $\begin{array}{l}\text { Vitamins etc } \\
\text { p-aminobenzoic acid } \\
\text { B12 } \\
\text { Biotin } \\
\text { Ca pantothenate } \\
\text { Choline chloride } \\
\text { Haemint } \\
\text { Myo-inositol } \\
\text { NAD } \\
\text { Nicotinic acid } \\
\text { Pyridoxal. HCl } \\
\text { Pyridoxal. phosphate } \\
\text { Pyridoxine. HCl } \\
\text { Thiamine. HCl } \\
\text { Thiamine pyrophosphate. } \mathrm{HCl}\end{array}$ & $\begin{array}{l}0.6 \\
0.01 \\
0.01 \\
0.6 \\
0 \\
0 \\
0 \\
0 \\
0 \cdot 6 \\
0 \\
0 \\
0.6 \\
0.6 \\
0\end{array}$ & $\begin{array}{l}0 \\
0 \\
0 \cdot 5 \\
2 \\
1 \cdot 4 \\
2 \\
0 \cdot 36 \\
2 \\
0 \\
0 \\
0 \\
0 \\
1 \cdot 0 \\
0 \cdot 46\end{array}$ & $\begin{array}{r}0 \\
0 \\
4 \\
20 \\
0 \\
0 \\
0 \\
10 \\
0 \\
0 \\
0 \\
0 \\
20 \\
20\end{array}$ & $\begin{array}{l}0 \cdot 13 \\
0 \cdot 10 \\
1 \\
5 \\
0 \\
0 \\
0 \\
2 \cdot 5 \\
0 \\
0 \\
0 \\
0 \\
0 \cdot 03 \\
1\end{array}$ & $\begin{array}{l}0 \\
0 \\
0 \cdot 75 \\
0 \\
3 \\
0 \\
0 \\
0 \\
0 \\
1 \\
0 \\
0 \\
0 \\
1 \cdot 05\end{array}$ & $\begin{array}{l}0 \\
0 \\
1 \\
1 \\
0 \\
0 \\
0 \\
2 \cdot 5 \\
0 \\
0 \\
1 \\
0 \\
1 \\
1\end{array}$ \\
\hline $\begin{array}{l}\text { Inorganic Salts } \\
\mathrm{CaCl} 2 \mathrm{H}_{2} \mathrm{O} \\
\mathrm{Fe}\left(\mathrm{NO}_{3}\right)_{3} .9 \mathrm{H}_{2} \mathrm{O} \\
\mathrm{KCl} \\
\mathrm{K}_{2} \mathrm{HPO}_{4} \\
\mathrm{KH}_{2} \mathrm{PO}_{4} \\
\mathrm{~K}_{2} \mathrm{SO}_{4} \\
\mathrm{Mg}_{2} \mathrm{Cl}_{2} .6 \mathrm{H}_{2} \mathrm{O} \\
\mathrm{MgSO}_{4} .7 \mathrm{H}_{2} \mathrm{O} \\
\mathrm{NH}_{4} \mathrm{Cl} \\
\left(\mathrm{NH}_{4}\right)_{2} \mathrm{SO}_{4} \\
\mathrm{NaCl} \\
\mathrm{NaHCO}_{3} \\
\mathrm{Na}_{2} \mathrm{SO}_{3}\end{array}$ & $\begin{array}{r}0 \\
0 \\
0 \\
0 \\
1000 \\
0 \\
0 \\
500 \\
0 \\
550 \\
5000 \\
0 \\
500\end{array}$ & $\begin{array}{r}37 \\
4 \\
0 \\
3480 \\
2720 \\
1000 \\
410 \\
0 \\
220 \\
0 \\
5800 \\
42 \\
0\end{array}$ & $\begin{array}{r}5 \\
5 \\
300 \\
10500 \\
4500 \\
900 \\
450 \\
0 \\
300 \\
0 \\
5250 \\
1000 \\
750\end{array}$ & $\begin{array}{r}0 \\
0 \cdot 2 \\
0 \\
4300 \\
1000 \\
0 \\
0 \\
400 \\
0 \\
500 \\
5000 \\
0 \\
0\end{array}$ & $\begin{array}{r}9 \cdot 2 \\
2 \dagger \\
0 \\
4100 \\
1750 \\
870 \\
407 \\
0 \\
214 \\
0 \\
5844 \\
1000 \\
0\end{array}$ & $\begin{array}{r}0 \\
4 \\
0 \\
4300 \\
1000 \\
0 \\
0 \\
400 \\
0 \\
500 \\
5000 \\
0 \\
0\end{array}$ \\
\hline $\begin{array}{l}\text { Others } \\
\text { EDTA } \\
\text { Polyyinyl alcohol } \\
\text { Na thioglycollate } \\
\text { Glutathione } \\
\text { Tween } 80 \\
\text { Soluble starch } \\
\text { Agar }\end{array}$ & $\begin{array}{r}0 \\
0 \\
0 \\
0 \\
0 \\
0 \\
8500\end{array}$ & $\begin{array}{r}3 \cdot 7 \\
5 \\
0 \\
0 \\
25 \\
0 \\
10000\end{array}$ & $\begin{array}{r}0 \\
0 \\
25 \\
0 \\
0 \\
1000 \\
10000\end{array}$ & $\begin{array}{r}0 \\
0 \\
0 \\
0 \\
0 \\
1000 \\
10000\end{array}$ & $\begin{array}{c}0.34 \\
0 \\
0 \\
31 \\
0 \\
1000 \\
10000\end{array}$ & $\begin{array}{r}0 \\
0 \\
0 \\
0 \\
0 \\
1000 \\
.10000\end{array}$ \\
\hline
\end{tabular}

- Hunter and McVeigh (1970); Catlin (1973); La Scolea and Young (1974); Heckels (Personal communication); Hendry and Stewart (1979); CGC = complete medium (see Methods). $\ddagger$ Dissolved in nitrolotriethanol; $†$ Ferric NH4 citrate. 


\section{MATERIALS AND METHODS}

Strains of N. gonorrhoeae. Test strains comprised 120 consecutive isolates from Avon collected in January and February 1982. Four strains were isolated from rectal swabs and one from a throat swab; the remainder were from urethral or cervical swabs or both. They were auxotyped when their identity had been confirmed and then stored at $-70^{\circ} \mathrm{C}$ in horse serum. Catlin's six reference strains (NCTC nos. 10928-10933) were tested on each occasion as controls.

Penicillin sensitivity testing. All strains were screened for $\beta$-lactamase production with a 10 $\mu \mathrm{g}$ penicillin disk; positive results were confirmed by the chromogenic cephalosporin test (O'Callaghan et al., 1972). The remainder were tested for penicillin susceptibility by the method of Shannon, Hedges and Edwards (1975).

Auxotyping media. Initial studies were performed using Heckels' medium (Dr J. E. Heckels, personal communication) (table I), which was progressively modified as described in the text. The composition of the final complete medium (CGC) used for routine auxotyping is given in table I. The set of typing media were prepared by omitting the appropriate factor from the complete medium. The ability of ornithine to replace an arginine requirement was tested by adding ornithine $100 \mu \mathrm{g} / \mathrm{ml}$ to arginine-free medium; an arginine requirement not satisfied by ornithine was designated $\mathrm{Arg}^{\circ}$. Strains that grew poorly were retested on media solidified with agarose in place of agar. Details of the preparation of the media will be supplied on request.

The liquid media used were identical with the corresponding solid media, except that agar and soluble starch were omitted. Other additions were made as described in the text.

Inoculation of defined media. After incubation for 18-24 h, growth from 'chocolate' agar

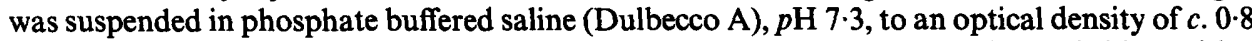
measured by a Unicam SP 500 spectrophotometer (Unicam Instruments Ltd, Cambridge) with a wavelength of $600 \mathrm{~nm}$ and path length $1 \mathrm{~cm}$. The suspension was immediately applied to each pre-dried auxotyping plate with a sterile cotton wool swab. A 'chocolate' agar plate was inoculated similarly. The plates were incubated in a humid atmosphere containing $5 \% \mathrm{CO}_{2}$ and growth recorded after 18-24 and 44-48 h. All strains were tested at least twice. During the investigation of growth rate on solid arginine-free media the plates were spread in the conventional manner for single colonies to evaluate colony size, number and morphology. Liquid media were dispensed aseptically in 10-ml amounts in metal capped universal containers, and incubated for $24 \mathrm{~h}$ at $36^{\circ} \mathrm{C}$ in an atmosphere containing $5 \% \mathrm{CO}_{2}$ with the caps loosened before use. These were inoculated with $0.1 \mathrm{ml}$ of a suspension of gonococci prepared as above, the caps tightened and the cultures incubated at $37^{\circ} \mathrm{C}$ in air. A $1-\mathrm{ml}$ sample was removed periodically and its optical density measured.

\section{RESULTS}

Initial testing of the 120 isolates in Heckels' medium showed that 15 isolates grew too poorly to enable auxotyping results to be reported confidently. Supplementing this medium with a mixture of threonine, tryptophan and tyrosine to concentrations found in CGC medium enabled another 13 strains to be auxotyped. The auxotyping results are shown in table II. We found that some strains that required Arg-Hyp-Ura grew less well on media solidified with agar than on media containing agarose.

On arginine-free medium some strains produced no growth after 18-24 h but profuse growth after $44-48 \mathrm{~h}$. When a selection of strains (NCTC no. 10928, two local prototrophic strains, and two local proline-requiring strains) were plated and spread conventionally, it became apparent that although there was no drop in the number of colonies on arginine-free medium compared with complete medium, they were smaller (fig. 1) but continued to grow on prolonged incubation. When ornithine was added to arginine-free medium the colonies grew as well as on complete medium. Examination by a plate microscope, illuminated to reveal Kellogg's colony types (Jephcott and Reyn, 1971) showed that there was no apparent difference in morphology. This led us 
TABLE II

Auxogroups of 120 consecutive isolates of $N$. gonorrhoeae

\begin{tabular}{lcc}
\hline Requirements & \multicolumn{2}{c}{ Number $(\%)$ of isolates } \\
\hline Zero (prototrophic) & 35 & $(29 \cdot 2)$ \\
Arg-Hyp-Ura & 33 & $(27 \cdot 5)$ \\
Pro-Arg & 15 & $(12 \cdot 5)$ \\
Pro-Arg-Ura & 12 & $(10)$ \\
Arg & 12 & $(10)$ \\
Pro & 8 & $(6 \cdot 7)$ \\
Pro-Met $(\beta$-lact) & 2 & $(1 \cdot 6)$ \\
Pro-Arg-Hyp-Ura & 1 & $(0 \cdot 8)$ \\
Failed to grow & 2 & $(1 \cdot 6)$ \\
\hline
\end{tabular}

Arg $=$ arginine requirement satisfied by ornithine.

$\mathrm{Arg}^{\circ}=$ arginine requirement not satisfied by ornithine.

$\beta$-lact = lactamase producers.

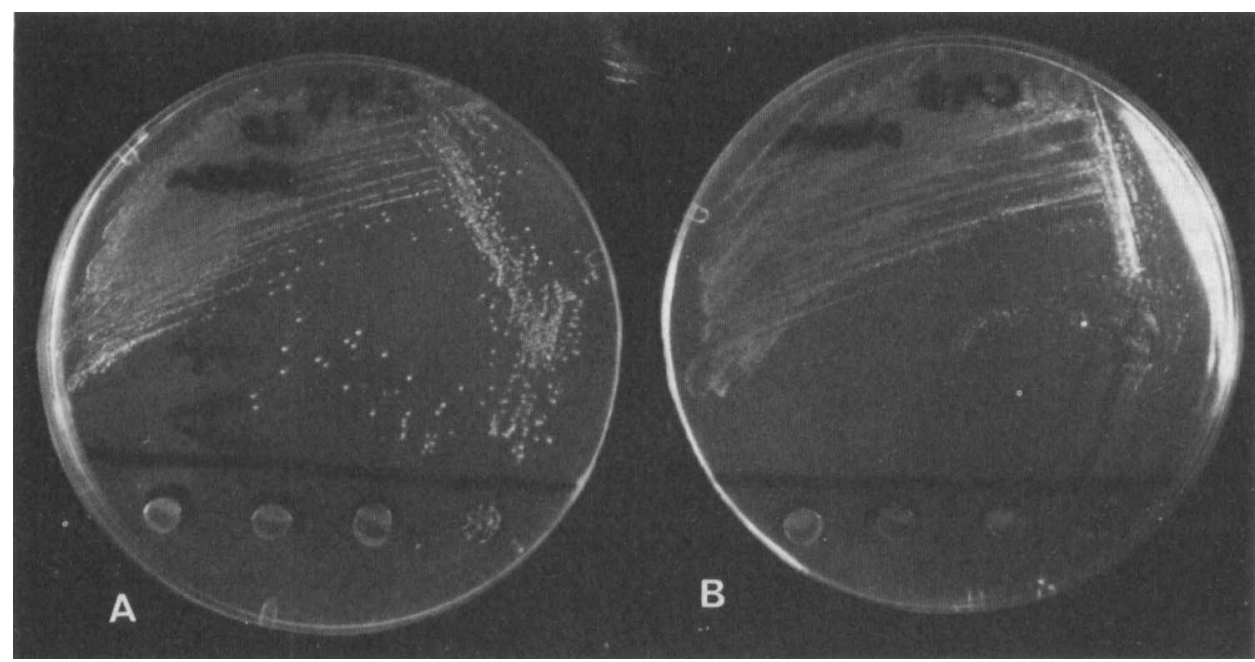

FIG. 1.-Growth of $N$. gonorrhoeae NCTC10928 on complete Heckels' medium (A) and arginine free medium (B).

to speculate that one or more enzymes before ornithine in the arginine pathway (fig. 2) may be inducible. Consequently we subcultured our five test strains daily for one week on both arginine-free and complete medium, before plating them on to a complete set of typing media. Colonies on the arginine free media were still smaller than colonies on other plates irrespective of the media used as a source for the subculture. It was of particular note, however, that the two proline-requiring strains showed some reversion to prototrophy when subcultured on arginine-free medium but none when subcultured on complete medium.

Further experiments showed that the addition of glutamate increased the colony size when added to arginine-free medium but not when added to proline-free medium. 


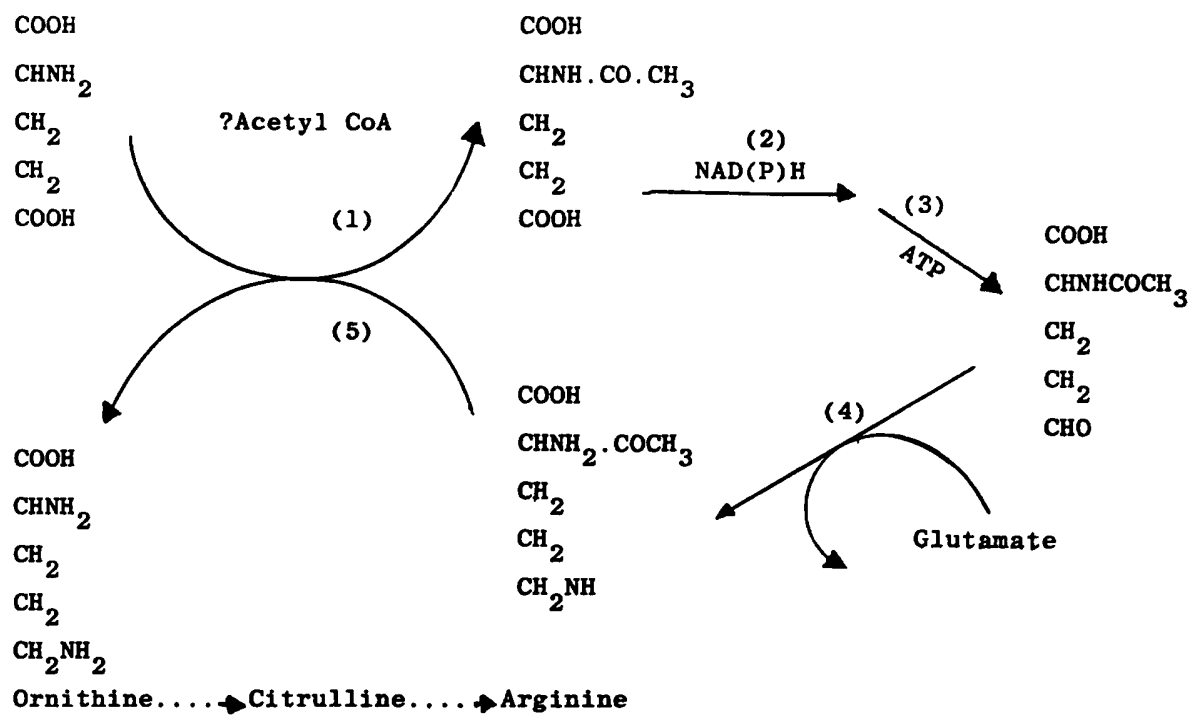

FIG. 2.-Part of the arginine biosynthetic pathway.

Pyridoxal $\mathrm{HCl}$, a catalyst in the arginine biosynthetic pathway, produced no increase in colony size. The results of the liquid culture experiment illustrated in fig. 3 confirm that the growth of the prototrophic strain in arginine-free medium is improved by increases in glutamate concentration. This growth paralleled the increase in colony size indicating that colony size measurement is an adequate monitoring criterion.

Table II shows the auxotyping results and fig. 4 shows the correlation between auxogroup and penicillin susceptibility. Prototrophic strains accounted for $29 \cdot 2 \%$ of isolates and were a heterogeneous group as judged by penicillin susceptibility testing. Strains requiring Arg-Hyp-Ura constituted the second largest group (27.5\%) with penicillin susceptibility in two ranges $(0.01-0.07 \mu \mathrm{g} / \mathrm{ml} ; 0.1-0.4 \mu \mathrm{g} / \mathrm{ml})$. The most homogeneous auxogroup with respect to penicillin susceptibility was the Pro-Arg ${ }^{\circ}-$ Ura group.

\section{Discussion}

The present work has established the relative frequency of auxotypes in and penicillin susceptibility of 120 strains of $N$. gonorrhoeae isolated in Britain. This is a necessary pre-requisite to any further studies designed to monitor genetic interchange within the gonococcal populations. For any system of typing to be useful, the results must be unequivocal and reproducible. In our initial auxotyping studies using Heckels' medium, 15 strains gave poor growth and did not meet the ideal requirements for a typing system. However, thirteen of these strains grew well when the medium was supplemented with threonine, tryptophan and tyrosine.

A further complication concerned the reading of results on arginine-free medium where the growth rate was slower. If the results were recorded only after $24 \mathrm{~h}$, strains could be designated as arginine requiring rather than non-requiring. Growth on an arginine-free medium supplemented with ornithine was equal to that on complete medium indicating that the rate-limiting step in the arginine biosynthetic pathway 


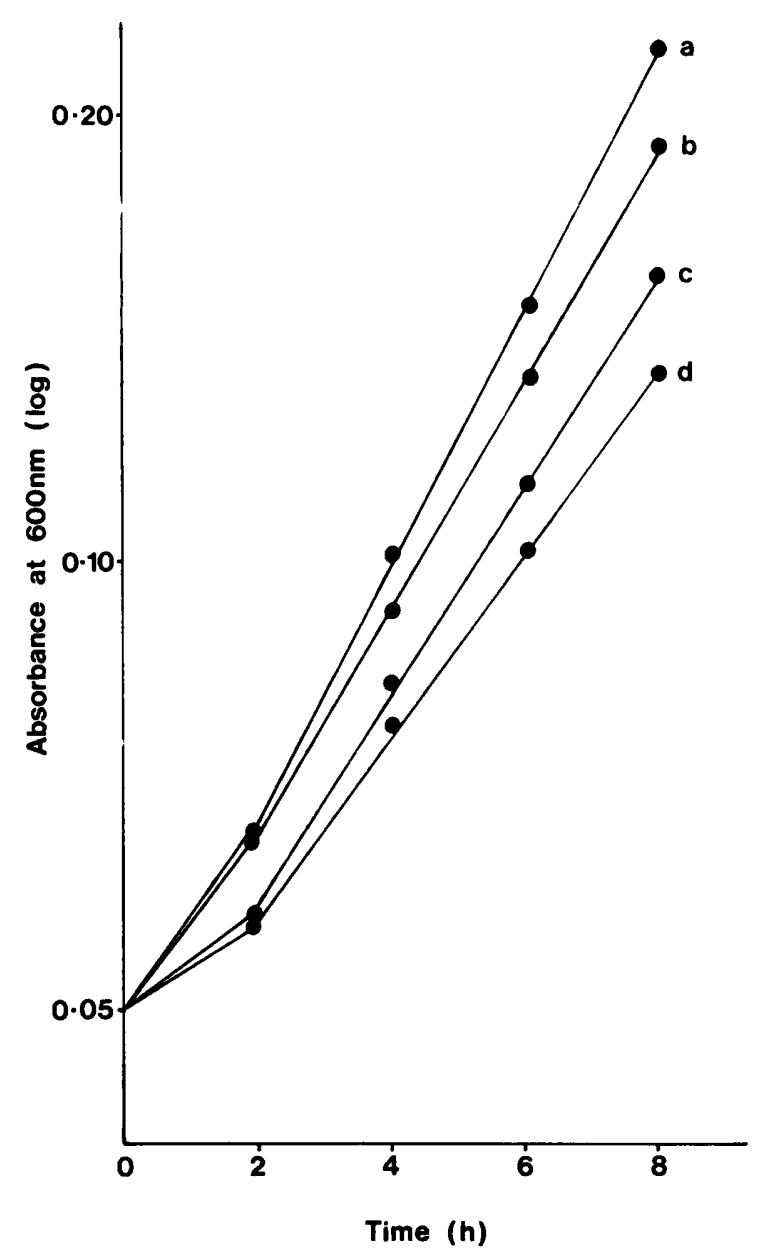

FIG. 3.-Growth of $N$. gonorrhoeae NCTC10928 in liquid media: (a) complete CGC medium; (b) arginine-free Heckels' medium plus glutamate $1000 \mu \mathrm{g} / \mathrm{ml}$; (c) arginine-free Heckels' medium plus glutamate $250 \mu \mathrm{g} / \mathrm{ml}$; (d) arginine-free Heckels' medium without additives.

must occur before ornithine (fig. 2). Further experiments showed that the growth on arginine-free medium was improved by increasing the glutamate concentration to a value near to that in Catlin's medium (Catlin, 1973). Other workers (table 1) use much lower concentrations of glutamate but have not reported this effect. It was unlikely that this growth phenomenon was due to inducible enzymes because growth of strains not requiring arginine was unaffected by sub-culture on medium with and without arginine before auxotyping. A further possibility could be that glutamate uptake was growth limiting. This is unlikely because growth of prototrophic strains on proline-free medium was normal and unaffected by an increased glutamate concentration. Pyridoxal plays a part in $\mathrm{N}$-acetylglutamine $\gamma$-semialdehyde transamination (reaction 4, fig. 2) and was included by Hendry and Stewart (1979) in their medium. However, addition of this co-factor to arginine-free medium did not improve the growth rate. Although we cannot pinpoint the rate-limiting step it is necessary to 


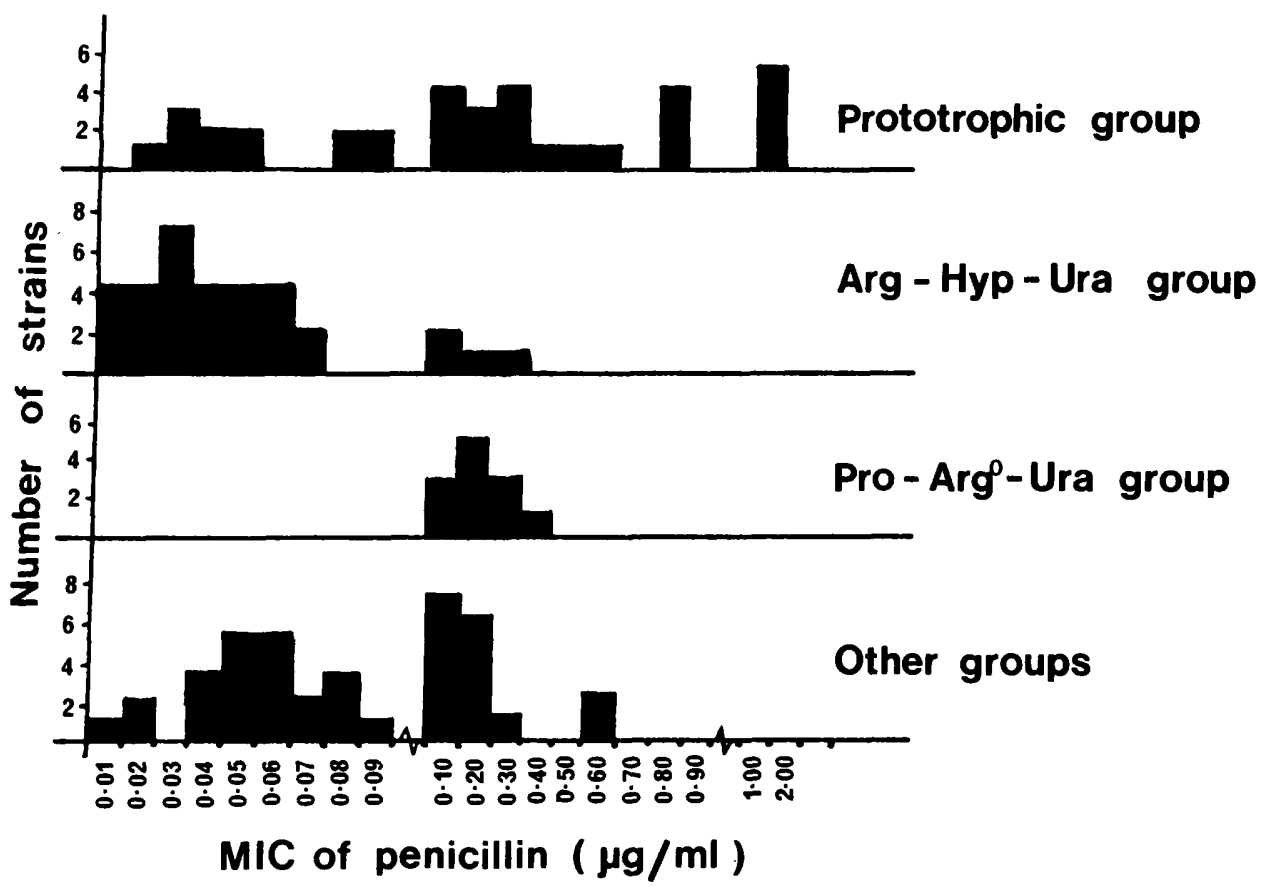

FIG. 4.-Distribution of penicillin sensitivities amongst different auxogroups of $N$. gonorrhoeae.

compensate for it in auxotyping media by increasing the glutamate concentration or making a final assessment of growth after a 48 -h period or both.

It was also observed that reversion to prototrophy occurred with proline-requiring strains when sub-cultured on arginine-deficient medium but not on complete medium. If this were a direct consequence of the slow growth then conditions of growth prior to auxotyping would be important.

Prototrophic strains were isolated most frequently $(29 \cdot 2 \%)$ and were also the most heterogeneous in penicillin susceptibility. Previous workers (Stewart and Hendry, 1979) have found a similar spread of sensitivity. The Arg-Hyp-Ura auxogroup has been found to be generally susceptible to penicillin and associated with disseminated gonococcal infections (Knapp and Holmes, 1975; Catlin and Reyn, 1982). We have found a similar penicillin susceptibility but despite this group representing $27.5 \%$ of our isolates, disseminated gonococcal infections were uncommon. The most homogeneous auxogroup in penicillin susceptibility was the Pro-Arg ${ }^{\circ}$-Ura group. This group corresponds with the Pro-Cit-Ura auxogroup reported recently by Hendry and Stewart (1979) in Canada. In common with the Canadian isolates they do not carry the cryptic plasmid of mol. wt $2.6 \times 10^{6}$ (Copley and Egglestone, 1982).

We are indebted to Dr A. E. Jephcott, Director of the Bristol Public Health Laboratory for granting permission and facilities to carry out this work.

\section{REFERENCES}

ANSINK-SChiPPER, M. C., VAN EMBDEN, J. D. A., VAN KLINGEREN, B. AND WoudSTRA, R. 1982. Further spread of plasmids among different auxotypes of penicillinase-producing gonococci. Lancet, 1, 445. 
Carifo, K. AND Catlin, B. W. 1973. Neisseria gonorrhoeae auxotyping: differentiation of clinical isolates based on growth responses on chemically defined media. Applied Microbiology, 26, 223-30.

CatuIN, B. W. 1973. Nutritional profiles of Neisseria gonorrhoeae, Neisseria meningitidis and Neisseria lactamica in chemically defined media and the use of growth requirements for gonococcal typing. Journal of Infectious Diseases, 128, 178-194.

CatuIn, B. W. AND REYN, A. 1982. Neisseria gonorrhoeae isolated from disseminated and localised infections in pre-penicillin era. Auxotypes and antibacterial drug resistances. British Journal of Venereal Disease, 58, 158-165.

COPLEY, C. G. AND EgGLestone, S. I. 1982. Gonococci without plasmids. Lancet, 1, 1133.

HeNDRY, A. T. AND STEWART, I. O. 1979. Auxanographic grouping and typing of Neisseria gonorrhoeae. Canadian Journal of Microbiology, 25, 512-521.

HunTER, K. M. AND MCVEIGH, I. 1970. Development of a chemically defined medium for growth of Neisseria gonorrhoeae. Antonie van Leeuwenhoek. Journal of Microbiology and Serology, 36, 305-316.

JePhCOT, A. E. AND ReYN, A. 1971. Neisseria gonorrhoeae. Colony variation 1. Acta Pathologica et Microbiologica Scandinavica, Section B, 79, 609-614.

JePHCOTT, A. E., EgGlestone, S. I. AND Copley C. G. 1982. Further evidence of dissemination of ability to produce penicillinase amongst gonococci. Lancet, 1, 1467-1468.

KNAPP, J. S. AND HOLMES, K. K. 1975. Disseminated gonococcal infections caused by Neisseria gonorrhoeae with unique nutritional requirements. Journal of Infectious Diseases, 132, 204-208.

KnapP, J. S., Thornsberry, C., Schoolnik, G. A., Wiesner, P. J., Holmes, K. K. and the Cooperative Study Group. 1978. Phenotypic and epidemiologic correlates of auxotype in Neisseria gonorrhoeae. Journal of Infectious Diseases, 138, 160-165.

LA SCOLEA, L. J. AND Young, F. E. 1974. Development of a defined minimal medium for the growth of Neisseria gonorrhoeae. Applied Microbiology, 28, 70-76.

LE FAOU, A., GUY, I. AND RIOU, J-Y. 1979. Auxotypes et sensibilités à six antibiotiques des souches de Neisseria gonorrhoeae isolée à Strasbourg en 1977-78. Annales de Dermatologie et Venereologie, 106, 267-272.

MoBerg, I. 1975. Auxotyping of gonococcal isolates. In Proceedings of the symposium on Genital Infections and their complications, edited by D. Danielsson, L. Juhlin and P-A. Mårdh. Almquist and Wiksell International, Stockholm, pp. 271-273.

NoBLE, R. C. 1980 . Characterisation of Neisseria gonorrhoeae from women with simultaneous infections at two sites. British Journal of Venereal Disease, 56, 3-5.

O'Callaghan, C. H., Morris, A., Kirby, S. M. AND ShINGler, A. H. 1972. Novel method for detection of $\beta$-lactamases by using a chromogenic cephalosporin substrate. Antimicrobial Agents and Chemotherapy, 1, 283-288.

Shannon, R., HeDGes, A. J. AND Edwards, R. J. 1975. Distribution of levels of penicillin resistance among freshly isolated strains of $N$. gonorrhoeae. Application of a novel sensitivity assay. British Journal of Venereal Disease, 51, 246-250.

STEWART, I. O. AND HENDRY, A. T. 1979. Association between the auxogroup of Neisseria gonorrhoeae and the minimal inhibitory concentration of penicillin. Sexually Transmitted Diseases, 6, 247-252. 